\title{
THE FUNCTIONS OF THE GEOSYNTHETICS IN ROADWAY APPLICATIONS
}

\author{
Kinga Brózda ${ }^{\square}$, Jacek Selejdak \\ Faculty of Civil Engineering, Częstochowa University of Technology, Częstochowa
}

\begin{abstract}
The aim of the study was to analyse the possibilities of using geosynthetics in communication engineering, especially road construction. The availability of geosynthetic products was described. These geosynthetics were classified and described in general due to the production method. Particular attention to the functions, which the geosynthetics can fulfill in roadway applications was paid. In details the possible location of geosynthetics in individual roadway layers was shown and then the performed functions were presented. It was also pointed out which of these functions the particular types of geosynthetics perform. In addition, the possibility of using the geogrids made of glass fibers and the geocomposites consisting of the fiberglass geogrid combined with a no-woven polypropylene were discussed. The benefits of using this type of geosynthetics were mentioned.
\end{abstract}

Key words: classification, location of geosynthetics, function, fiberglass geosynthetics

\section{INTRODUCTION}

For many years, the effective techniques of strengthening both soil in road construction and roadway pavement were sought. Most often these techniques of strengthening is performed in order to increase the resistance of roadway, to reduce the effects of appeared settlement and another external influence. In order to meet a number of functions that significantly contribute to the improvement of roadway performance and subgrade quality, geosynthetics are successfully used (Gradkowski, 2007; Kazimierowicz-Frankowska, 2013; Szczygielski \& Stopa, 2014; Keller, 2016).

\section{THE CLASSIFICATION OF THE GEOSYNTHETICS}

Currently, the availability of geosynthetics is very high. In accordance with the PN-EN ISO 10318-
$-1: 2015$ standard on geosynthetic (GSY) it is possible to define it as a generic term describing a product, at last one of whose components is made from a synthetic or natural polymer, in the form of a sheet, a strip or a three - dimensional structure, used in contact with soil and/or other materials on geotechnical and civil engineering applications. The geosynthetics can generally be categorized based on the production method. In the technical literature the following categories are recognized: geotextiles, geogrids, geonets, geomembranes, geosynthetic clay liners, geopipes, geofoams and geocomposites (Horodecki \& Duszyńska, 2017). However, according to the PN-EN ISO 10318-1:2015 standard on geosynthetics (GSY) it is possible to divide them into the following groups:

- geotextile (GTX), which include: no-woven geotextile (GTX-NW), knitted geotextile (GTX-K), woven geotextile (GTX-W); 
- geotextile-related product (GTP), which include: geogrid (GGR), geonet (GNT), geomat (GMA), geocell (GCE), geostrip (GST), geospacer (GSP);

- geosynthetic barrier (GBR), which include: polymeric geosynthetic barier (GBR-P), clay geosynthetic barier (GBR-C), bituminous geosynthetic barier (GBR-B);

- geocomposite (GCO).

These types of the geosynthetics are described and characterized in Table 1 (Bathurst, 2007; Koerner, Hsuan \& Koerner, 2007; Palmeira, Tatsuoka, Bathurst, Stevenson \& Zornberg, 2008; Duszyńska \& Sikora, 2014).

Such a wide assortment of geosynthetic products enables proper selection of design parameters to ensure optimal quality and roadway performance.

\section{FUNCTIONS OF THE GEOSYNTHETICS IN ROADWAY APPLICATIONS}

The particular types of the geosynthetics are design to fulfill specific functions. The main functions of the geosynthetics, which are reported in the technical literature (Koerner et al., 2007; Palmeira et al., 2008; Szruba, 2014; PN-EN ISO 10318-1:2015), include:

- separation - means a separation of the subsoil from the structural layer, or separation of individual structural layers from aggregates with dissimilar parameters. Placed between two different material, the geosynthetic keeps the functionality and integrity of these two materials and sometimes provides a long-term stress relief. The main design properties to fulfill this function concern its survivability during installation;

Table 1. The classification of the geosynthetics and descriptions

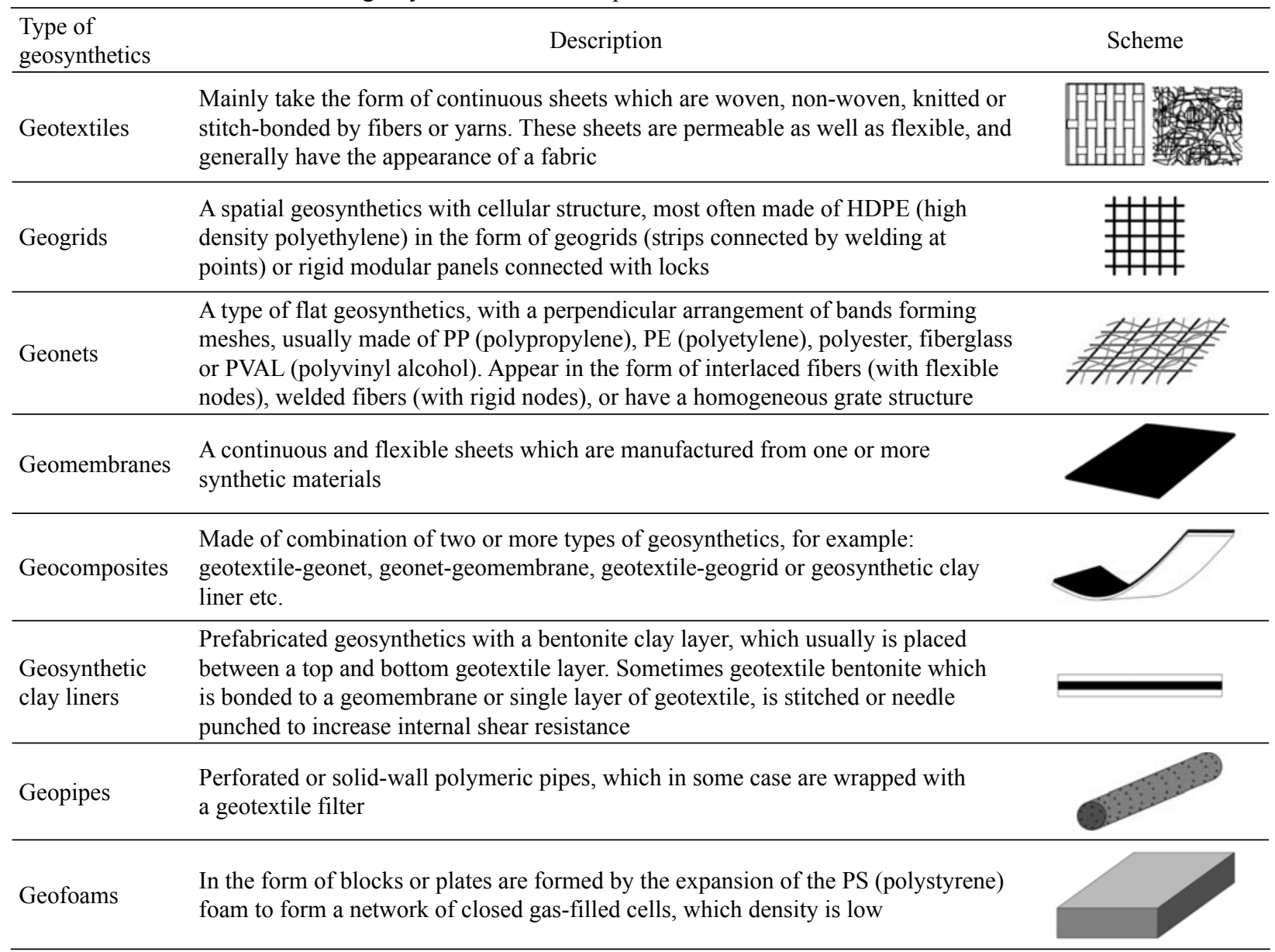


- filtration - a free liquid flow between soil layers, while maintaining the intact structure of the soil phase. The geosynthetic retains fine particles on its upstream. The main design properties to fulfill this function are a permittivity (cross-plane hydraulic conductivity per unit thickness) and measures its pore-size distribution;

- drainage - an ability to drain liquids (or gasses) within the plane of the geosynthetic's structure. The main design property to fulfill this function is a transmissivity which is an in-plane hydraulic conductivity in relation to the thickness;

- reinforcement - includes the reinforcement of the soil (to improve the mechanical properties of soil, structural layers, as well as slope stability conditions) and reinforcement of the roadway pavements (to reinforce the bituminous masses with geosynthetics, also to enhance the surface of dirt roads). The main design property to fulfill this function is a tensile strength of geosynthetic;

- surface erosion control - use of a geosynthetic materials to prevent or limit soil or other particle movements at the surface of, for example, a slope. Produces a tensile forces which control the deformations in the soil-geosynthetic composite (Zornberg, 2017). The main design property to fulfill this function is the stiffness of the soil-geosynthetic composite;

- protection - means a protection against mechanical damage of other geosynthetics, against falling rock fragments and also as an additional fixation of other geosynthetics. The geosynthetic creates a cushion above or below other material with the purpose of minimize damage during placement of other overlying materials. The main design properties to fulfill this function concern its puncture resistance;

- barrier - minimizes the cross-plane flow of liquids or gasses and provides containment of it. The main design property to fulfill this function concerns a long-term durability of the geosynthetic;

- stress relief - (for asphalt overlay) use of a geosynthetic to retard the development of cracks by absorbing the stresses arise from the damaged pavement. These listed functions are used, among others, to improve the utility parameters of the roadway. Therefore, in roadway applications the geosynthetics are used in order to limit the reflective cracking in asphalt overlays, to stabilize the road base and road subgrade, to provide separation and lateral drainage (Zornberg, 2017).

The possible geosynthetic locations in the paved road section were presented in the figure (Gradkowski, 2007; Zornberg, 2017). Various functions that these geosynthetics can meet in selected locations were also submitted.

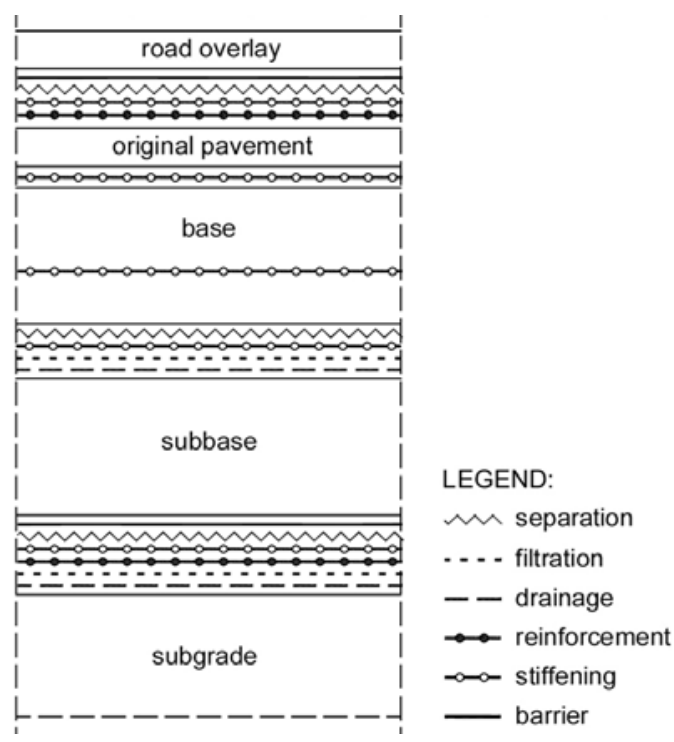

Fig. Selected functions of geosynthetics fulfilled depending on various location in roadway layer (based on Gradkowski, 2007; Zornberg, 2017)

Table 2. Functions of the geosynthetics depending on their types

\begin{tabular}{|c|c|c|c|c|c|c|}
\hline \multirow[b]{2}{*}{$\begin{array}{l}\text { Type } \\
\text { of geosynthetic }\end{array}$} & \multicolumn{6}{|c|}{ Function } \\
\hline & 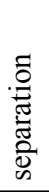 & 鶕 & 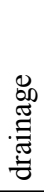 & 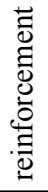 & 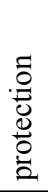 & כ] \\
\hline Geotextiles & + & + & + & + & + & \\
\hline Geogrids & & & & + & & \\
\hline Geonets & & & + & & & \\
\hline Geomembranes & + & & + & & & + \\
\hline Geosynthetic clay liners & & & & & & + \\
\hline Geopipes & & & + & & & \\
\hline Geofoams & + & & & & & \\
\hline Geocomposites & + & + & + & + & + & + \\
\hline
\end{tabular}


The various types of the geosynthetics are successfully used to fulfill one or more specific functions in a variety of roadway applications (Szruba, 2014; Zornberg, 2017). Table 2 shows which types of geosynthetics meet selected functions.

\section{THE FIBERGLASS GEOSYNTHETICS IN ROADWAY APPLICATIONS}

The resistance of the asphalt overlays to the formation of the cracks and their propagation can be considered as one of the most important mechanical property (Grabowski \& Pożarycki, 2006). The reinforcement of roadway made of geosynthetics can in a significant way delay this propagation process of asphalt pavement cracks. Undeniably important issue is checking the effectiveness and efficiency of using these materials as the reinforcement of asphalt surfaces. One of the increasingly common solutions is the use of glass fiber reinforced geosynthetics. The fiberglass reinforced plastics (FRP) geogrid has a broad scope of use because of high strength and stability, very good resistance to environmental factors and also creep, which are achieved by the appropriate choice of the raw material, production process and quality index (Brózda, Selejdak \& Koteš, 2017). Efficacy of this type of solution were demonstrated by Zhesheng, Hao, Qingshan and Chunlong (2015). It was proved, among others, that it is possible to strength the interface bonding by using glass fiber reinforced asphalt membranes and there is potential to limit the reflection cracking of asphalt concrete (AC) overlay on Portland cement concrete (PCC) pavements.

The most common is the use of glass fiber geogrids or geocomposites consisting of a fiberglass geogrid combined with a no-woven polypropylene. Then the meshes of such a geogrid are created by longitudinal and transverse arrangement of the fibers (warp and weft). The warp and weft are interlaced in the nodes so that the warp can be moved along the weft, which allows the course of the fibers to match the grains of the asphalt layer. In some cases, this type of mesh is also soaked with asphalt to merge glass fibers, to protect the fibers from mechanical damage as well against the effects of chemical substances, and improving ad- hesion to asphalt layers (Mujah, Ahmad, Hazarika \& Safari, 2013; Qingbiao et al., 2015).

Geosynthetics made of glass fiber reinforced plastics are widely used in the field of strengthening due to the high strength parameters, good ductility and resistance to environmental factors, resistance to creep and high stability (Brózda et al., 2017). The benefits of using this type of geosynthetics can also include the reduction of ruts resulting from high ambient temperatures, intensive loads from vehicle wheels, and also extended fatigue life of pavements.

\section{SUMMARY}

The improvement of the roadway performance and quality of the subgrade is possible by using various types of the geosynthetics. These geosynthetics are able to meet a number of specific functions, often more than one. On the base of the theoretical studies and practical applications the extension of service life of flexible pavements by installing geosynthetics was proved. Moreover, some of the geosynthetics (for example geogrid) can be applied in the new constructions and also rehabilitation of existing asphalt pavements.

Especially in the roadway applications, the geogrids placed at the interface of bituminous layers improve the rutting resistance and prevent or totally eliminate the reflective cracking. In addition, depending on the geosynthetic's location in the paved road section, it is possible to achieve the required effect on the structure of the roadway. However, it is important to pay attention on the design property of the geosynthetic products. It is necessary to fulfill the specific functions.

Recently, there is also a growing interest in modern materials for the geosynthetic's production, such as FRP with glass fibers, especially as the reinforcement of asphalt overlays. The reason is, among others, very good properties of the raw material. Nevertheless, in order to improve the techniques of strengthening the roadway surfaces as well as the ground soil in road construction, the theoretical studies and practical applications are still recommended. 


\section{REFERENCES}

Bathurst, R. J. (2007). Geosynthetics Classification. IGS Leaflets on Geosynthetics Applications. Austin, TX: IGS Education Committee.

Brózda, K., Selejdak, J. \& Koteš, P. (2017). Analysis of Properties of the FRP Rebar to Concrete Structures. Applied Engineering Letters, 2 (1), 6-10.

Duszyńska, A. \& Sikora, Z. (2014). Dobór wyrobów geosyntetycznych do zbrojenia gruntu. Inżynieria Morska $i$ Geotechnika, 35 (5), 468-473.

Grabowski, W. \& Pożarycki, A. (2006). Badania i ocena propagacji spękań zmęczeniowych w modelu nawierzchni asfaltowej. Drogi i Mosty, 5 (1), 5-18.

Gradkowski, K. (2007). Geosyntetyki w budowie dróg. Zasady stosowania geosyntetyków o n-tym kierunku wzmocnienia. Inżynier Budownictwa, 7/8, 36-41.

Horodecki, G. \& Duszyńska, A. (2017). Dobór geotekstyliów i wyrobów pokrewnych pełniących funkcję zbrojenia w budownictwie komunikacyjnym - wybrane problemy inżynierskie. Magazyn Autostrady, 11-12, 42-46.

Kazimierowicz-Frankowska, K. (2013). Geosyntetyczne zbrojenie jako jeden ze sposobów wzmocnienia podłoża gruntowego w budownictwie drogowym. Magazyn Autostrady, 4, 50-57.

Keller, G. R. (2016). Application of geosynthetics on low-volume roads. Transportation Geotechnics, 8, 119-131. https://doi.org/10.1016/j.trgeo.2016.04.002

Koerner, G. R., Hsuan, Y. G. \& Koerner, R. M. (2007). The durability of geosynthetics. Chapter 3. In R. W. Sarsby (ed.), Geosynthetics in Civil Engineering (pp. 36-65). Cambridge: Woodhead Publishing Series in Textiles. https://doi.org/10.1533/9781845692490.1.36
Mujah, D., Ahmad, F., Hazarika, H. \& Safari, A. (2013). Evaluation of the mechanical properties of recycled glass fibers-derived three dimensional geomaterial for ground improvement. Journal of Cleaner Production, 52, 495-503.

Palmeira, E. M., Tatsuoka, F., Bathurst, R. J., Stevenson, P. E. \& Zornberg, J. G. (2008). Advances in Geosynthetics Materials and Applications for Soil Reinforcement and Environmental Protection Works. Electronic Journal of Geotechnical Engineering, 13, Special Issue State of the Art in Geotechnical Engineering, 1-38.

PN-EN ISO 10318-1:2015. Geosyntetyki. Część 1: Terminy i definicje [Geosynthetics. Part 1: Terms and definitions].

Qingbiao, W., Cong, Z., Xiaokang, W., Rongshan, L., Xunmei, L. \& Shide, L. (2015). Development and Properties of Glass Fiber Reinforced Plastics Geogrid. Journal of Wuhan University of Technology (Materials Science Edition), 30 (3), 520-527.

Szczygielski, M. \& Stopa, Ł. (2014). Usage of new soil improvement techniques in road embankment constructions. Technical Transactions Civil Engineering, 2-B (6), 109-116.https://doi.org/10.4467/2353737XCT.14.118.2568

Szruba, M. (2014). Geosyntetyki, cz. 1. Charakterystyka i funkcje wg PN-EN ISO 10318:2007. Nowoczesne Budownictwo Inżyieryjne, 55 (4), 48-51.

Zhesheng, G., Hao, W., Qingshan, Z. \& Chunlong X. (2015). Glass fiber reinforced asphalt membrane for interlayer bonding between asphalt overlay and concrete pavement. Construction and Building Materials, 101 (1), 918-925. https://doi.org/10.1016/j.conbuildmat.2015.10.145

Zornberg, J. G. (2017). Functions and Applications of Geosynthetics in Roadways. Procedia Engineering, 189, 298-306. https://doi.org/10.1016/j.proeng.2017.05.048

\section{ZASTOSOWANIE GEOSYNTETYKÓW W BUDOWNICTWIE DROGOWYM}

\section{STRESZCZENIE}

Podstawowym celem pracy była analiza możliwości wykorzystania geosyntetyków w inżynierii komunikacyjnej, a w szczególności w budownictwie drogowym. Opisano rodzaje dostępnych produktów geosyntetycznych. Zaprezentowano klasyfikację geosyntetyków ze względu na metodę produkcji oraz krótko scharakteryzowano dostępne na rynku wyroby geosyntetyczne. Szczególną uwagę zwrócono na funkcje i zastosowanie, jakie geosyntetyki mogą spełniać w podłożach nawierzchni drogowych. Dokładnie opisano miejsce wbudowania geosyntetyków w poszczególnych warstwach drogowych oraz pełnione przez nie funkcje oraz wskazano, które z nich realizowane są przez poszczególne rodzaje geosyntetyków. Ponadto omówiono możliwość wykorzystania geosiatek wykonanych z włókien szklanych i geokompozytów składających się z siatki z włókna szklanego połączonej z geowłókniną polipropylenową. Wskazano również zalety zastosowania tego typu geosyntetyków.

Słowa kluczowe: klasyfikacja, umiejscowienie geosyntetyków, funkcja, geosyntetyki z włókna szklanego 